\title{
ARTERIAL HYPERTENSION-NON INVASIVE DIAGNOSIS
}

\author{
DR MILAN ADAMEK M.D. \\ Spa Podebrady a.s. \\ 29033 Podebrady \\ Czech Republic
}

\begin{abstract}
Aims \& Objectives: This study was designated to find and to characterize similarities andf differencies between two groups of patiens. One group were patients with established arterial hypertension / $\mathrm{AH} /$ and the second one were patients with new diagnosis of $\mathrm{AH}$ or who have so called high normal blood pressure / BP / or who had randomly found elevated blood pressure once time in their history but, therefore they had normal BP on check examinations, they were left without treatment. The main goal of the study was to show that the groups are similar in important parameters, which may be of clinical importance / decision about treatment / and to find which of the non invasive examinations, with exception of classical BP measurements, may still play the important role in setting the diagnosis of $\mathrm{AH}$ in early stage of the disease. And the second main goal of the study was to show that measurement of BP under basal conditions may sometimes be insufficient for decision making if the patient is hypertonic or not. Methods: Following methods and measurements were used to obtain necessary parameters - arterial blood pressure measurement, echocardiographic examination to obtain values as left ventricular diameter in systole and diastole, interventricular septum and posterior wall thickness in systole and diastole, ejection fraction - Teichholz, interventricular septum and posterior wall excursions, left atrial diameter, measurement of speed of aortic ejection, E/A index, isovolumic relaxation time, carotid myointimal thickening, carotid pulse velocity, time to peak of carotid upstroke and ambulatory blood pressure and electrocardiogram monitoring, measurement of blood pressure reaction on exercise stress testing and in recovery period post exercise and double product.
\end{abstract}

Key words: $\quad$ Arterial hypertension - non invasive examination - early diagnosis

\section{INTRODUCTION}

Essential arterial hypertension / $\mathrm{AH} /$ is the main risk factor in the development of aterosclerosis. At the present time we have possibility to diagnose $\mathrm{AH}$ at the early stage of disease.

It is known that $\mathrm{AH}$ is as the aterosclerosis the self perpetuating process. So, when we have qualified suspicion on this disease we should immediately start with antihypertensive therapy.

In this work is shown that between patients with new diagnosis of $\mathrm{AH}$, or who have so called normal high blood pressure, or who had once time elevated BP in their history and than normal BP on check examinations under basal conditions and patients with defined diagnosis of $\mathrm{AH}$ exist great similarity in observed parameters, especially in blood pressure reaction on 
exercise and in the development of blood pressure in recovery phase post exercise.

46 patients, otherwise healthy as to the cardiovascular system, with less or more elevated blood pressure at admission or at history or high normal blood pressure and 108 patients with established diagnosis of hypertensive arterial disease were studied. Under normal conditions the patients from the first group would be recommnended only to change and improve their lifestyle, as to the increase their physical activity, sufficient relaxation, stress reduction, body weight reduction, salt intake lowering etc. And they are summoned to checks of their BP after certain time periods for example after one year / 1, 2, 3 /. But we should be more active in this situation.

It was decided to put these patients through all of these above mentioned examinations inclusive exercise stress testing in order to find certain differencies or similarities on noninvasive examination between both groups.

\section{METHODS}

Following parameters were measured - arterial blood pressure, echocardiographic values as left ventricular diameter in systole and diastole, interventricular septum and posterior wall thickness in systole and diastole, ejection fraction - Teichholz, interventricular septum and posterior wall excursions, left atrial diameter, speed of aortic ejection, E/A index, isovolumic relaxation time, carotid myointimal thickening, carotid pulse velocity, time to peak of carotid upstroke and ambulatory blood pressure and electrocardiogram monitoring, blood pressure reaction in single stages of exercise stress testing and in single stages of recovery period post exercise and double product.

The results were analysed by means of Student's t-test and the median and frequency rates were determined for different graphs.

\section{RESULTS}

Baseline characteristics of the patients of both groups are presented in Table 1. Group 2 are patients with chronic $\mathrm{AH}$, group 1 are patients with new diagnosis of $\mathrm{AH} /$ this group includes - patients with high normal $\mathrm{BP}$ , patients with single or sporadic elevation of BP in their history - they were left without treatment, and patients with slight elevation of BP for the first time in their life at admission /. Light but statistically significant difference between the groups was found only in the following parameters - IVSD, IVSS, PWD, PWS, LA, E/A, CMIT, patient's age.

\begin{tabular}{|c|c|c|c|c|c|c|c|c|c|c|c|}
\hline \multicolumn{12}{|c|}{ Table-I Comparison of Data Values in Both Groups of Patients } \\
\hline \multirow[t]{2}{*}{ Variable } & \multicolumn{11}{|c|}{$\begin{array}{c}\text { t-tests; grouped: new and chronic AH: }=\text { if }(\mathrm{V} 3-3 ; 1 ; 2) \text { (Data) } \\
1-\text { New diagnosis AH } \\
2-\text { Chronic AH }\end{array}$} \\
\hline & Aver 1 & Aver 2 & $t$ & sv & $p$ & $\begin{array}{c}\text { Nu. } \\
\text { Val. } 1\end{array}$ & $\begin{array}{l}\text { Nu. } \\
\text { Val. } 2\end{array}$ & S. Dev.1 & S. Dev.2 & $\begin{array}{c}\text { F-ratio } \\
\text { disp }\end{array}$ & $P$ dis \\
\hline LVS & 32.38889 & 31 & 1.318203 & 140 & 0.189588 & 36 & 106 & 5.0442487 & 5.5942147 & 1.229944 & 0.491752 \\
\hline LVD & 49.77778 & 49.00943 & 0.653096 & 140 & 0.514766 & 36 & 106 & 602614974 & 6.0434857 & 1.073449 & 0.761628 \\
\hline IVSD & 10.83333 & 12.01887 & -3.91519 & 140 & 0.000141 & 36 & 106 & 1.7647339 & 1.4990863 & 1.385815 & 0.209813 \\
\hline IVSS & 14.52778 & 15.91509 & -3.7273 & 140 & 0.00028 & 36 & 106 & 2.0630921 & 1.8828445 & 1.200628 & 0.474202 \\
\hline PWD & 9.916667 & 11.25472 & -4.20539 & 140 & 0.000046 & 36 & 106 & 1.9621417 & 1.531021 & 1.642474 & 0.056706 \\
\hline PWS & 13.86111 & 15.34906 & -3.84168 & 140 & 0.000185 & 36 & 106 & 2.016401 & 2.0049579 & 1.011447 & 0.93049 \\
\hline EFTCH & 62.97222 & 66.41509 & -1.82861 & 140 & 0.069587 & 36 & 106 & 10546458 & 9.4836882 & 1.236684 & 0.408914 \\
\hline elVs & 6.25 & 7.086538 & -302105 & 138 & 0.003003 & 36 & 104 & 1.1051826 & 1.5271687 & 1.90944 & 0.031326 \\
\hline
\end{tabular}




\begin{tabular}{|c|c|c|c|c|c|c|c|c|c|c|c|}
\hline ePW & 11.55556 & 11.38679 & 0.539585 & 140 & 0.590341 & 36 & 106 & 1.5936381 & 1.6304878 & 1.046781 & 0.905904 \\
\hline LA & 34.11111 & 36.64151 & -2.6394 & 140 & 0.009247 & 36 & 106 & 6.0934521 & 4.5338697 & 1.806295 & 0.022845 \\
\hline Ao & 1.183333 & 1.238585 & -1.28708 & 140 & 0.200191 & 36 & 106 & 0.1674685 & 0.2380774 & 2.021016 & 0.01945 \\
\hline$E / A$ & 1.444444 & 2.066038 & -3.6119 & $140^{\circ}$ & 0.000423 & 36 & 106 & 0.7725448 & 0.9285818 & 1.444751 & 0.215156 \\
\hline IVRT & 0.103333 & 0.110394 & 1.91291 & 138 & 0.057832 & 36 & 104 & 0.0210442 & 0.0183765 & 1.311402 & 0.297297 \\
\hline CMIT & 0.062917 & 0.070604 & -3.17456 & 140 & 0.001846 & 36 & 106 & 0.0129491 & 0.0124179 & 1.087386 & 0.725981 \\
\hline CPV & 0.133389 & 0.135802 & -0.69734 & 140 & 0.486745 & 36 & 106 & 0.0170215 & 0.0182331 & 1.147434 & 0.656803 \\
\hline TTP & 0.200472 & 0.205123 & -0.7162 & 140 & 0.475061 & 36 & 106 & 0.0322982 & 0.0341023 & 1.114838 & 0.73196 \\
\hline aveBPexeS & 215.4815 & 215.5338 & -0.01276 & 140 & 0.989839 & 36 & 106 & 20.513092 & 21.504613 & 1.099008 & 0.770434 \\
\hline aveBRexeD & 122.3542 & 121.0715 & 0.436667 & 140 & 0.663026 & 36 & 106 & 15.17193 & 15.24509 & 1.009667 & 1 \\
\hline aveBPrecs & 175.2431 & 177.5236 & -0.52519 & 140 & 0.600284 & 36 & 106 & 22.210075 & 22.609509 & 1.036292 & 0.934552 \\
\hline aveBPrecD & 109.5139 & 105.9953 & 1.125968 & 140 & 0.262106 & 36 & 106 & 15.670371 & 16.372232 & 1.091584 & 0.78891 \\
\hline Age ave. & 51.08333 & 60.60952 & -4.17078 & 139 & 0.000053 & 36 & 105 & 12.836054 & 11.466083 & 1.253236 & 0.38209 \\
\hline \multicolumn{12}{|c|}{$\begin{array}{c}\text { I Legend : LVS and LVD - left ventricular diameter in systole and diastole, IVSD, IVSS, PWD and PWS - thickness interventricular } \\
\text { septum and posterior wall of left ventricle in systole and diastole, EFTCH - ejection fraction Teichholz, eIVS and ePW - excursions of } \\
\text { IVS and PW, LA - left atrium diameter, Ao-speed of aortic ejection, E/A index - filling of left ventricle, IVRT - isovolumic relaxation } \\
\text { time, CMIT - carotid myointimal thickening, CPV - carotid pulse velocity - time to upstroke of carotid pulse wave, TTP - time to peak of } \\
\text { carotid pulse wave, aveBPexeS, aveBPexeD - average of BP in systole and diastole at the end of exercise, aveBPrecS, ave BP recD - } \\
\text { average BP in systole and diastole during recovery period, Age ave - average age. T-test characteristic, sV - degree of freedom, } p \\
\text { - dispersion, Nu.val. - number of valid, S.dev. - standard deviation, F-ratio disper.- ratio of dispersion / }\end{array}$} \\
\hline
\end{tabular}

\section{Ambulatory blood pressure monitoring:}

29 patients, i.e. $30,5 \%$ of one's from the group with diagnosed $\mathrm{AH}$ had maximal levels of $\mathrm{BP}$ during monitoring period lower than $140 / 90 \mathrm{mmHg}$.

21 patients, i.e. $40,6 \%$ of one's from the group with new diagnosis of $\mathrm{AH}$ had maximal levels of $\mathrm{BP}$ during period of monitoring lower than $140 / 90 \mathrm{mmHg} /$ blood pressure under $140 / 90 \mathrm{mmHg}$ on Holter BP monitoring is mostly left unremarkable /.

Ambulatory electrocardiogram monitoring in both groups was, with exception of unfrequent supraventricular and ventricular extrasystoles, unnoticeable.

\section{Data from transthoracalechocardiography:}

53 patients, i.e. $40 \%$ from the group with diagnosed $\mathrm{AH}$ had left ventricular hypertrophy / IVS and PW thickness above $12 \mathrm{~mm} / .7$ patients, i.e. $15,5 \%$ from the group with new diagnosed AH had left ventricular hypertrophy. 24 patients, i.e. $25 \%$ from the group with diagnosed $\mathrm{AH}$ had enlarged left atrium / more than $40 \mathrm{~mm} / .7$ patients, i.e. $14,6 \%$ from the group with new diagnosed $\mathrm{AH}$ had enlarged left atrium.

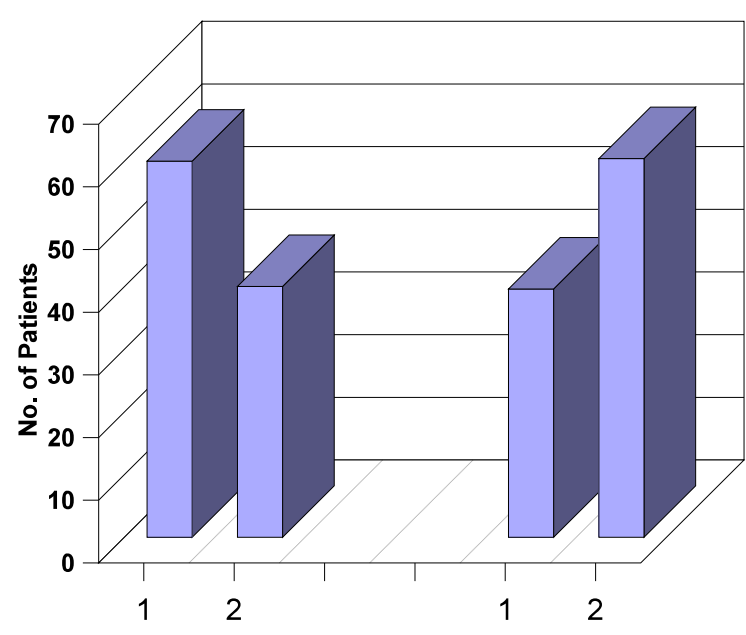

Fig.1 Distribution of the $E / A$ index in both groups. $60 \%$ of patients from the group with diagnosed $\mathrm{AH}$ and $40 \%$ of patients with new diagnosis of $\mathrm{AH}$ had abnormal E/A filling index. There is shift to more abnormal 
Ejection fraction was in normal limits in both groups. E/A index - filling of left ventricle was less than one in $60 \%$ of patients in the group with diagnosed $\mathrm{AH}$ and in $39,6 \%$ in the group with new diagnosed $\mathrm{AH}$.

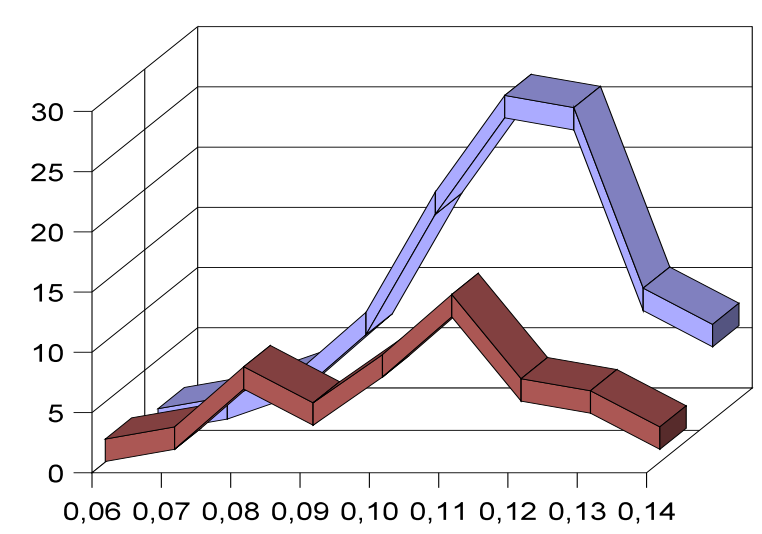

Fig.2 Distribution of the values of IVRT / isovolumic relaxation time /. There is evident shift to higher values in the group with diagnosed $\mathrm{AH}$. Median for the group with defined $\mathrm{AH}$ is 0,1100 and for the group with new $\mathrm{AH} 0,1025$, but the difference is statistically not significant.

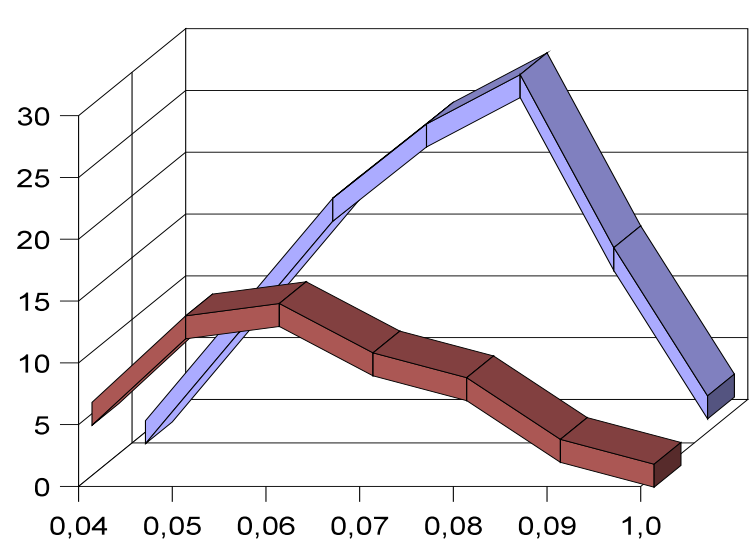

Fig.3 Distributin of the values of CMIT / carotid myointimal thickening 1. There is evident shift of the values of the group with defined $\mathrm{AH}$ to the right to higher values. Median for the group with defined $\mathrm{AH}$ is 0,7000 and for the other group 0,6000. The difference between both rows is statistically significant. Patients with established $\mathrm{AH}$ had more thickened carotid myointima.

Further data and results are introduced on the following figures.

\section{Exercise stress testing:}

All patients of both groups have undergone exercise stress testing on bicycle ergometer. 121 probands, i.e. $83,4 \%$ patients had hypertensive reaction on exercise / blood pressure higher than $220 / 120 \mathrm{mmHg} / .84,2 \%$ of patients in the group with defined $\mathrm{AH}$ and $85,4 \%$ of patients in the group with new diagnosed $\mathrm{AH}$ had hypertensive reaction on exercise.

The course of exercise pressure reaction and the development of pressure reaction in the postexercise recovery phase is shown on the Fig. 5 and Fig.6.
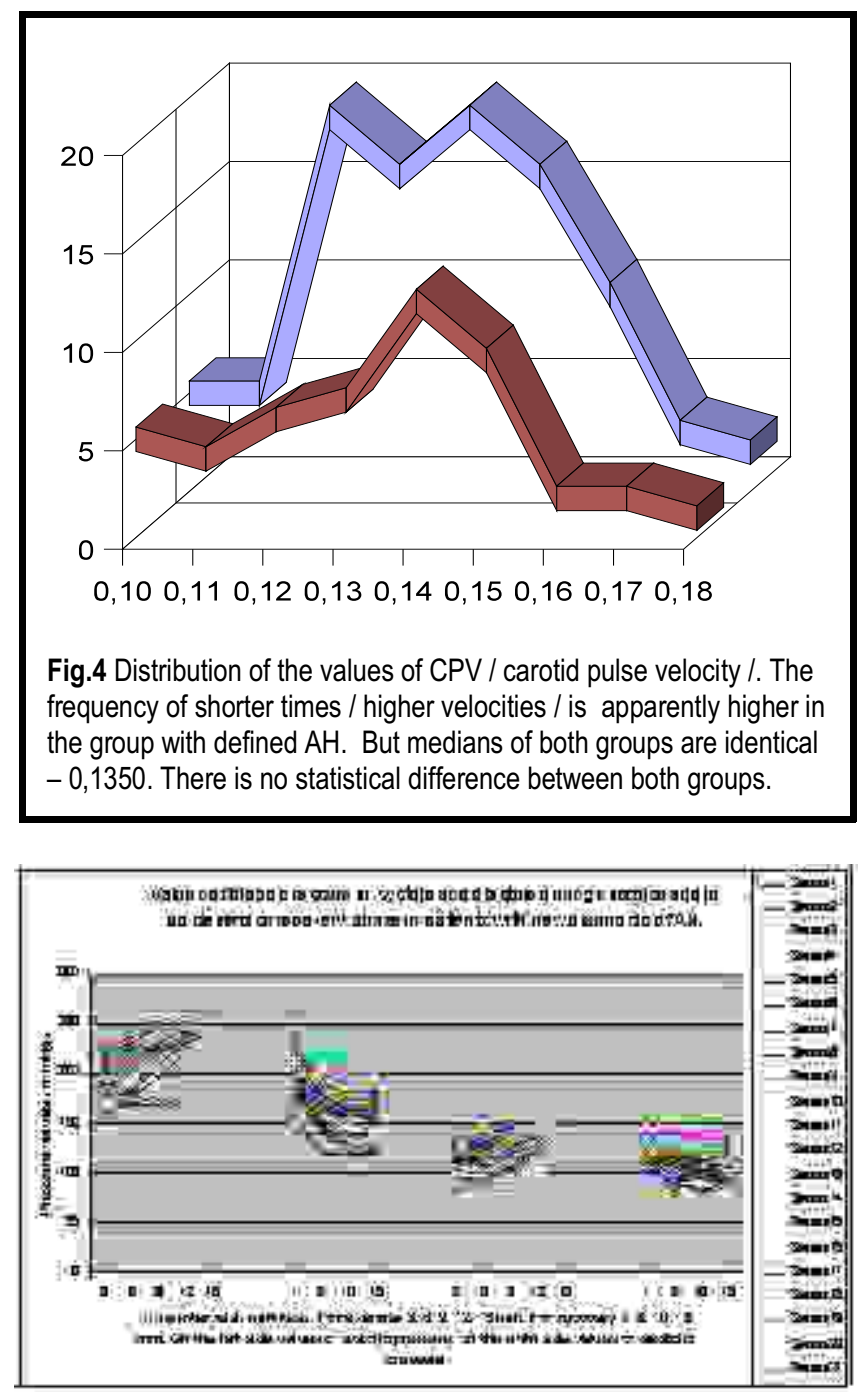

\section{DISCUSSION}

The statistically significant difference / $p<0.05$ / between both groups was obtained in the following parameters - 
IVSD, IVSS, PWD, PWS, LA, E/A index, IVRT, CMIT, double product. The finding of these differencies is logical therefore in the course of development of $\mathrm{AH}$ there is increased incidence of myocardial hypertrophy, enlargement of left atrium, increased thickness of carotid myointima while double product and maximal heart frequency are decreasing. At present this is natural

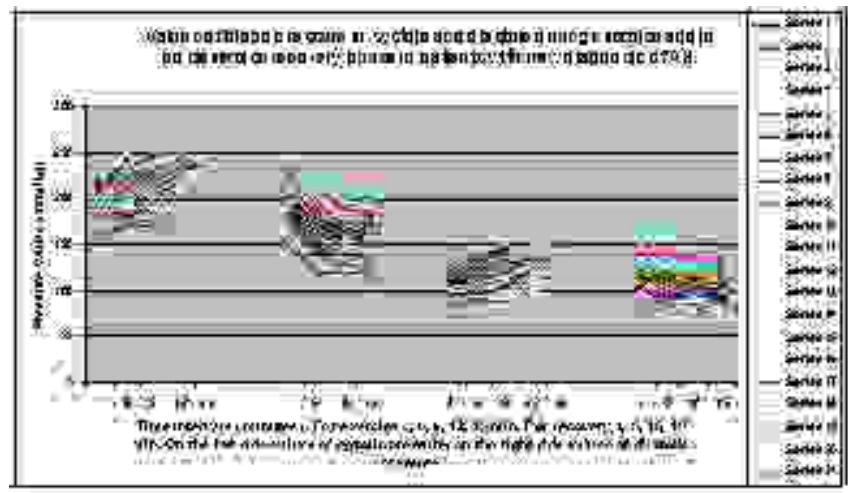

development of $\mathrm{AH}$ in most of patients, despite our medical treatment.

There was no statistically significant difference between both groups of patients in the following parameters CPV, TTP, average watts loading at the end of exercise and in the values of $\mathrm{BP}$ in the indivudual stages of exercise and recovery period / $p>0.05 /$.
The values of CPV and TTP are identical. It could be explained, that in the group with diagnosed $\mathrm{AH}$, there is reduced compliance of arterial wall / higher value of CMIT / and in consequence higher speed of blood flow. In the group with new diagnosed $\mathrm{AH}$ it may be due to hyperkinetic circulation. These data are evidence that different groups of patients were examined.

The identical BP reaction and development of BP at exercise and in the recovery period in both groups of patients is rather striking. The averaged, distribution and trend curves are in both groups identical. / Fig.5, Fig.6 and Table 2 \%. If we take hypertensive reaction on exercise and the abnormal course of BP in recovery period as a risk factor for development of $\mathrm{AH} / 4,5$ / then the above mentioned results confirm the usefullness of exercise stress testing in patients in early stages of $\mathrm{AH}$ and in ones with so called high normal BP and in ones with single BP elevations in their history. We should also acccept the fact that to measure BP under so called basal conditions / when the patient is inactive at easy / may be insufficient to decide if the patient is already hypertonic or not hypertonic. We can use exercise testing for assessmen of the disease and for decision making about antihypertensive therapy.

\begin{tabular}{|c|c|c|c|c|c|c|c|c|c|c|}
\hline \multicolumn{10}{|c|}{ t-tests; grouped: new and chronic AH: = if (V3 - 3; 1;2) (Data) } \\
1- New diagnosis AH \\
2- Chronic AH
\end{tabular}




\begin{tabular}{|c|c|c|c|c|c|c|c|c|c|c|}
\hline 15 minexeD & 135 & 129 & 1 & 4 & 1 & 2 & 4 & 21 & 10 & 4.2 \\
\hline 1 minrecs & 204 & 202 & 0 & 140 & 1 & 106 & 106 & 28 & 25 & 1.2 \\
\hline 1 minretcD & 113 & 119 & -1 & 140 & 0 & 106 & 106 & 18 & 19 & 1 \\
\hline 5 minrecs & 176 & 173 & 1 & 140 & 1 & 106 & 106 & 24 & 25 & 1 \\
\hline 5 minrecD & 105 & 109 & -1 & 140 & 0 & 106 & 106 & 18 & 17 & 1.2 \\
\hline 10 minrecs & 166 & 165 & 0 & 140 & 1 & 106 & 106 & 24 & 26 & 1.1 \\
\hline 10 minrecD & 103 & 107 & -1 & 140 & 0 & 106 & 106 & 16 & 17 & 1.1 \\
\hline 15 minrecs & 164 & 161 & 1 & 140 & 0 & 106 & 106 & 24 & 24 & 1 \\
\hline 15 minrecD & 103 & 103 & 0 & 140 & 1 & 106 & 106 & 17 & 16 & 1.1 \\
\hline
\end{tabular}

As is shown there is no statistically significant diffrence in BP values during exercise and recovery period practically identical. between both groups of patients. The measured data are

\begin{tabular}{|c|c|c|c|c|c|c|c|c|c|c|c|}
\hline \multirow[t]{2}{*}{ Variable } & \multicolumn{11}{|c|}{$\begin{array}{l}\text { t-tests; grouped: new and chronic AH: }=\text { if }(\mathrm{V} 3-3 ; 1 ; 2) \text { (Data) } \\
\text { 1- New diagnosis AH } \\
\text { 2- Chronic AH }\end{array}$} \\
\hline & Aver 1 & Ave 2 & $\mathrm{t}$ & sv & $p$ & No.. Val. 2 & No.. Val. 1 & $\mathrm{~S} \operatorname{dev} .2$ & $\mathrm{~S}$ dev.1 & $\begin{array}{l}\text { F-ratio } \\
\text { disp }\end{array}$ & $P$ disp \\
\hline IVRT & 0 & 0 & 2 & 138 & 0 & 104 & 36 & 0 & 0 & 1 & 0 \\
\hline CMIT & 0 & 0 & 3 & 140 & 0 & 106 & 36 & 0 & 0 & 1 & 1 \\
\hline CPV & 0 & 0 & 1 & 140 & 0 & 106 & 36 & 0 & 0 & 1 & 1 \\
\hline
\end{tabular}

The exercise stress testing is advisable still from another reason. Therefore $40,6 \%$ of patients from the group with new $\mathrm{AH}$ had unremarkable result during ambulatory BP monitoring / maximum BP was less than $140 / 90 \mathrm{mmHg} /$, but if these patient have undergone exercise stress testing then $85,4 \%$ of them had hypertensive reaction.

\section{CONCLUSION}

1. measurement of blood pressure under so called basal conditon must not be sufficient for well timed decision making if the patient is or is not hypertonic

2. regime arrangements and life style changes must not be sufficient to treat the patient even in the situation of only light elevation of blood pressure
3. hypertensive blood pressure reaction on exercise is not dependent od duration of the disease at all

4. it may be advisable to engage exercise testing to the spectrum of examinations in $\mathrm{AH}$, especially in earliest stages of the disease, in the situation of accidentaly measured higher blood pressure and during observation of the efficacy of the antihypertensive therapy.

It is clear from the study that blood pressure reaction on exercise and in the postexercise recovery period is the diagnostic factor of greatest value from the spectrum of used measurements. If we accept the fact that hypertensive reaction on exercise stress testing is definitive risk factor for development af arterial hypertension than we have also accept the fact that 
blood pressure should not be measured only under so called basal conditions especially in patients with high normal blood pressure, who can have normal blood pressure when inactive at ease, who can have even normal blood pressure on ambulatory BP monitoring. Hypertensive reaction on exercise is one of the important diagnostic moments and signs in the earliest clinical stadium of arterial hypertension at present. And if we have hypertensive reaction on stress in this group of patients than we could immediately start with antihypertensive therapy and not to recommend only changes in life style and not to wait until the patient shifts himself to the group with elevated blood pressure under basal conditions. It seems, that measurement of BP only under basal conditions may be insufficient for exclusion of AH especially in early stage of the disease. We should be more active.

Stress dosing and exercise stress testing should be the part of our antihypertensive diagnostic armaments.

\section{REFERENCES}

1. Arterial Stiffness and Pulse Wave Velocity, Asmar R., Elsevier, 1999, ISBN 2-84299-148-6-Z2

2. Arteries in Clinical Hypertension, M. Sofor, co. Lippincott-Raven, 1994, ISBN 0-397-51484

3. Cardiac Rehabilitation, adult Fitness and exercise Testing, Fardy, Yanowitz, $3^{\text {rd }}$ Edition, c.1995, Williams\&Wilkins, ISBN 0-683-03031-0

4. Cecil Textbook of Medicine, Bennet and Plum, $20^{\text {th }}$ Edition, / page 257, 258 / W.B.Saunders Co., / 1 / ISBN 0 7216-3561-X

5. Clinical cardiac Rehabilitation, Pashkow, Dafoe, 2nd Edition,c.1999, Williams\&Wilkins, ISBN 0-683-30224-8

6. Dyslipidemie, Widimský J., Triton, ISBN 1998, 80-8587570-5

7. Echocardiography, Feigenbaum H. $5^{\text {th }}$ Edition, C.Lea Febiger 1994, ISBN 0-8121-1692-5

8. Echokardiografie, Gregor P., Widimský P., Niederle P., Avicenum, 1984, ISBN 80-201-0092

9. Ergometry in the Assessment of arterial Hypertension, Cardiology 1985, 72: 147-159

10. Evaluating the Impact of Population and high Risk Strategies for the primary Prevention of cardiovascular Disease, European Heart Journal, Vol. 25, Nr.6, March 2004, 484-492, ISSN 0195-668X.

11. Exercise and the Heart, Froelicher . Myers, 4th Edition, c.2000, W.B.Saunders Co., ISBN 0-7216-8450-5

12. Farmakoterapie ischemické choroby srdeční, Widimský J., Grada Publishing s.r.o., 1997, ISBN 807169-273-5

13. Heart Disease, Braunwald, 6th Edition, c.2001, / page 149, 943, 944, 945 /W.B.Saunders Co., / 2, 3, 4, 5 / ISBN 0-7216-566-8

14. Heart Disease, Braunwald E., $5^{\text {th }}$ Edition, C.1997, W.B Saunders Co., ISBN 0-7216-5666-8

15. Historie léčby hypertenze, Widimský J., Triton, 2001, ISBN 80-7254-176-5

16. Hypertenze, Widimsky J.et al., 2. rozšiřené vydání, Triton 2004; / 452 / ISBN 80-7254-515-9

17. Hypertenze - bulletin České společnosti pro hypertensi, 5/2004, ISSN : 1211-9679

18. Hypertenze - bulletin České společnosti pro hypertenzi, 2/2004, ISSN1211-9679

19. Hypertenze - bulletin České společnosti pro hypertensi, 1/2005, ISSN : 1211-6979

20. Ischemická choroba srdeční, c.2000, Špinar,1.vydání, Grada, ISBN 80-247-0500-1

21. Kardiologie, Štejfa, 1.vydání, c.1998, Grada, ISBN 907169-448-7

22. Merck Manual, 14th Edition, 1986, National Publishing Company,Philadelphia

23. MSD, Kompendium klinické medicíny, The Merck Manual, 1.české vydání, Praha 1996

24. New Approaches to Managing multiple Risk Factors in cardiovascular Disease, European Heart Journal Supplements, Vol6, Supp.G, December 2004, ISSN 1520 $756 \mathrm{X}$

25. Sekundární hypertenze u pacientů vyšetřených na specializovaném pracovišti, B.Štrauch et al., Cor et Vasa, 2005, Nr.2, 70-72.

26. Sekundární prevence po infarktu myokardu, Widimský J., Triton, 1999, ISBN 80-7254-0580

27. Textbook of internal Medicine, Kelley, c.1997, Raven Publisher, ISBN 0-397-51283-X

28. The Heart, Hurst, 5tth Edition, Mc Graw-Hill Book Company, C.1982.

29. VALUE for Blood Pressure. Výsledky studie VALUE potvrdily zásadní význam poklesu krevního tlaku, J.Špinar J. Vítovec, Cor et Vasa, 2004, Nr.9, 447-449.

30. Význam detekce preklinické aterosklerózy, Lékařské listy, číslo 7, roč.50, 26-30.

31. Zátěžová echokardiografie, Chaloupka V., Elbl L., Maxdorf Jessenius, 1997, ISBN 80-85800-76-4

32. Zátěžové testy $\mathbf{v}$ echokardiografii, Widimský J., Lefflerová K., Triton, 2000, ISBN 80-7254-095-5 